\title{
Treatment of adult isolated ulnar diaphyseal fractures: A comparison of new-generation locked intramedullary nail and plate fixation
}

\author{
Erişkin izole ulna diyafiz kırıklarının tedavisi: \\ Yeni nesil kilitli intramedüller çivi ve plak fiksasyonunun karşılaştırılması
}

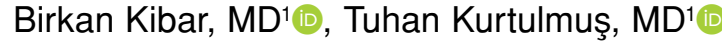

'Department of Orthopedics and Traumatology, Haydarpaşa Numune Training and Research Hospital, İstanbul, Turkey ${ }^{2}$ Department of Orthopedics and Traumatology, Kartal Dr. Lütfi Kırdar Training and Research Hospital, İstanbul, Turkey
\end{abstract}

\section{ABSTRACT}

Objectives: This study aims to compare the radiological and functional results of adult patients with isolated ulnar diaphyseal fractures treated with plate and new-generation locked intramedullary nail (IMN).

Patients and methods: The study included 57 patients (38 males, 19 females; mean age 39.1 years; range, 18 to 77 years) with isolated ulnar diaphyseal fractures treated with IMN or plate fixation between January 2008 and December 2017. Thirty patients (Plate group) were treated with plate fixation and 27 patients (IMN group) with IMN. Functional results were evaluated according to the Grace-Eversmann evaluation system and the disabilities of the arm, shoulder and hand (DASH) questionnaire.

Results: The mean union time was $12.8 \pm 1.2$ weeks in the IMN group and $13.7 \pm 1.4$ weeks in the plate group $(p=0.092)$. The mean operation time was significantly shorter in the IMN group (30 minutes) than in the plate group (46 minutes; $\mathrm{p}<0.001)$. The mean DASH score was $7.0 \pm 4.5$ in the IMN group and $7.7 \pm 8.6$ in the plate group $(\mathrm{p}=0.766)$.

Conclusion: With similar union rates, functional results, and shorter operation times, locked IMNs are a suitable alternative to plate osteosynthesis in adult isolated ulnar diaphyseal fractures.

Keywords: Adult, internal fixation, locked intramedullary nail, plating, reduction, ulnar fracture.

Isolated ulnar diaphyseal fractures in adult patients are rare, with a significant number of these fractures occurring as a result of the forearm being raised to protect against direct impact. ${ }^{[1,2]}$ In many studies,

\section{ÖZ}

Amaç: Bu çalışmada plak ve yeni nesil kilitli intramedüller çivi (İMÇ) ile tedavi edilen izole ulna diyafiz kırı ̆̆ olan erişkin hastaların radyolojik ve fonksiyonel sonuçları karşılaştırıldı.

Hastalar ve yöntemler: Çalışmaya Ocak 2008 - Aralık 2017 tarihleri arasında İMÇ veya plak fiksasyonu ile tedavi edilen izole ulna diyafiz kırı $\breve{g}_{1}$ olan 57 hasta (38 erkek, 19 kadın; ort. yaş 39.1 yıl; dağılım, 18-77 yıl) dahil edildi. Otuz hasta (Plak grubu) plak fiksasyonu ve 27 hasta (İMÇ grubu) İMÇ ile tedavi edildi. Fonksiyonel sonuçlar Grace-Eversmann değerlendirme sistemi ve kol, omuz ve el sorunları (DASH) anketine göre değerlendirildi.

Bulgular: Ortalama kaynama süresi İMÇ grubunda $12.8 \pm 1.2$ hafta ve plak grubunda $13.7 \pm 1.4$ hafta idi $(\mathrm{p}=0.092)$. Ortalama ameliyat süresi İMÇ grubunda (30 dakika) plak grubundan (46 dakika; $\mathrm{p}<0.001$ ) anlamlı derecede k1sa idi. Ortalama DASH skoru İMÇ grubunda $7.0 \pm 4.5$ ve plak grubunda $7.7 \pm 8.6$ idi $(\mathrm{p}=0.766)$.

Sonuç: Benzer kaynama oranları, fonksiyonel sonuçlar ve daha kısa ameliyat süreleriyle kilitli İMÇ'ler erişkin izole ulna diyafiz kırıklarında plak osteosentezine uygun bir alternatiftir

Anahtar sözcükler: Erişkin, internal fiksasyon, kilitli intramedüller çivi, plaklama, redüksiyon, ulna kırı̆̆ı.

satisfactory union rates and functional results have been reported with conservative treatment methods such as below- and above-elbow casts, functional braces, and compressive bandages. ${ }^{[3-8]}$ Surgical

Received: April 16, 2019 Accepted: July 08, 2019 Published online: October 24, 2019

Correspondence: Birkan Kibar, MD. Haydarpașa Numune Eğitim ve Araştırma Hastanesi Ortopedi ve Travmatoloji Kliniği, 34668 Kadıköy, İstanbul, Turkey. Tel: +90 216 - 5423232 e-mail: birkankibar545454@gmail.com 
treatment is recommended for angulation of more than $10^{\circ}$ and translation of more than 50\%. ${ }^{[9]}$ Anatomic reduction is achieved with plate fixation, which is a commonly used treatment method with high union rates that provides angular and rotational stability and allows early movement. ${ }^{[10]}$ However, plate fixation has a number of disadvantages, such as requiring large skin incisions, the disruption of blood support due to wide periosteal and muscle dissection, the discharge of the fracture hematoma, the distortion of periosteal circulation due to plate contact, skin irritation due to the implants, and refractures after plate removal.[11] Intramedullary nails (IMNs) are a good alternative to plate fixation, offering less disruption to the blood supply due to reduced periosteal dissection, smaller scars, and lower refracture rates after the removal of the implant, ${ }^{[12]}$ while new generation locked IMNs exhibit high union rates. ${ }^{[13,14]}$

In this study, we aimed to compare the radiological and functional results of adult patients with isolated ulnar diaphyseal fractures treated with plate and new-generation locked IMN.

\section{PATIENTS AND METHODS}

This study was conducted at Haydarpaşa Numune Training and Research Hospital between January 2008 and December 2017 and retrospectively assessed a total of 91 patients with isolated ulnar diaphyseal fractures treated with IMNs or plate fixation. Fractures with angulation of more than $10^{\circ}$ or translation of more than $50 \%$ underwent surgery. Pathological fractures $(n=2)$, patients with additional injuries in the same extremity $(n=6)$, distal and proximal metaphyseal fractures $(n=4)$, Monteggia fractures $(n=2)$, olecranon fractures $(n=17)$, proximal and distal radioulnar joint injuries $(n=1)$, or those with a follow-up period of less than one year $(n=2)$ were excluded. Finally, 57 patients (38 males, 19 females; mean age 39.1 years; range, 18 to 77 years) were included. In our clinic, some surgeons prefer to use IMN in ulnar diaphyseal fractures while others prefer to use plate. Preoperative implant selection was in accordance with the surgeon's personal preference. The study protocol was approved by the Haydarpaşa Numune Training and Research Hospital Ethics Committee. A written informed consent was obtained from each patient. The study was conducted in accordance with the principles of the Declaration of Helsinki.

Patients were divided into two groups as plate $(n=30)$ and IMN group $(n=27)$. In the plate group, $3.5 \mathrm{~mm}$ limited contact dynamic compression plates and dynamic compression plates were used
(Figure 1). One type of nail was used for all patients in the IMN group (TST Union Medical Devices San. ve Tic. Ltd. Sti., Istanbul, Turkey). Ulnar IMNs were applied with a unreamed approach. Distal locking was performed by applying one or more locking screws to the eight transverse clefts in the distal $3 \mathrm{~cm}$ portion of the nail, proximal locking was conducted using proximal round, oval, and proximal oblique holes, and stability was achieved (Figure 2).

In the IMN group, reduction was provided with mini open incisions for six patients. No grafts were used in either group. Active elbow, forearm, and wrist exercises were started in the IMN group on the first
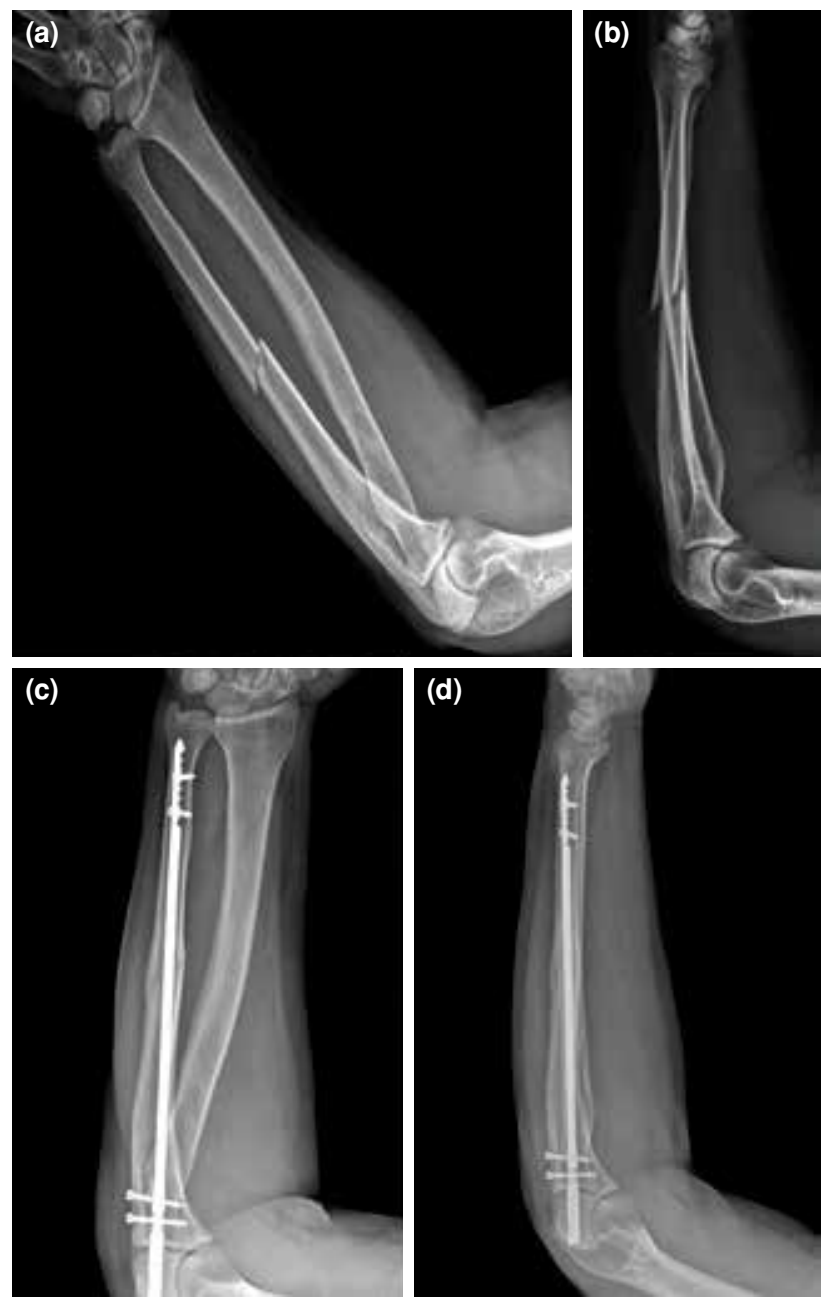

Figure 1. Forty-two-year-old male patient, right ulnar middiaphyseal fracture (Association for Osteosynthesis/Association for the Study of Internal Fixation type b). (a, b) Preoperative anteroposterior and lateral radiographs. (c, d) Postoperative $14^{\text {th }}$ month anteroposterior and lateral radiographs showing healed fracture. 

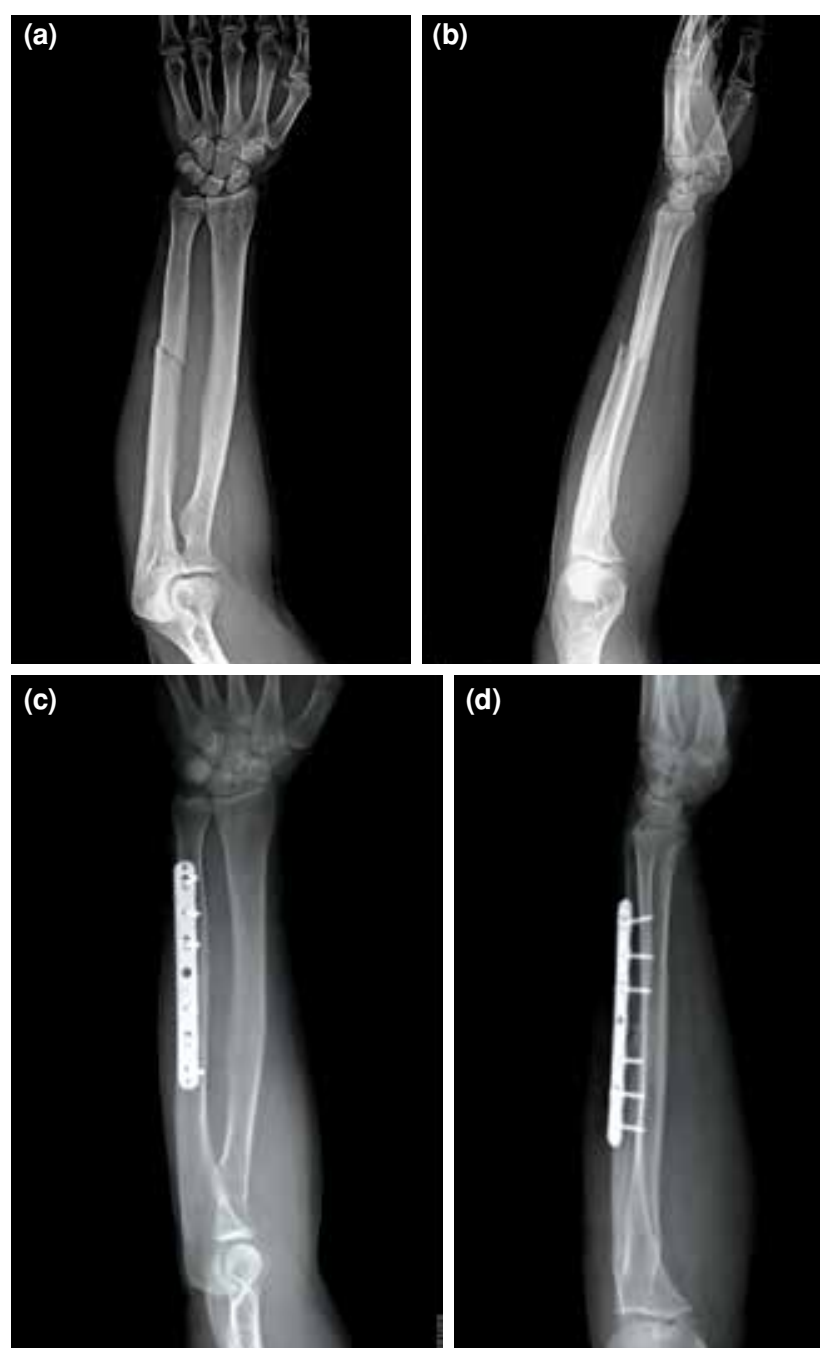

Figure 2. Sixty-one-year-old male patient, left ulnar middiaphyseal fracture (Association for Osteosynthesis/Association for the Study of Internal Fixation type a). (a, b) Preoperative anteroposterior and lateral radiographs. (c, d) Postoperative $12^{\text {th }}$ month anteroposterior and lateral radiographs showing healed fracture.

postoperative day. In the plate group, above-elbow plaster casts were applied with $90^{\circ}$ elbow flexion and forearm neutral rotation for two-three weeks, after which active movement was instigated.
In anteroposterior and lateral radiographs, cortical trabeculation and bridging callus formation on the fracture line and the lack of tenderness in the fracture line with palpation were used to confirm bone union. ${ }^{[15]}$

Grip strength was measured with a Saehan hydraulic hand dynamometer (Saehan Corporation, Changwon, South Korea). In addition, the GraceEversmann evaluation system and the disabilities of the arm, shoulder and hand (DASH) questionnaire were used to assess the patients. ${ }^{[15,16]}$ Evaluation was performed by another blinded orthopedic surgeon who contributed to the study.

\section{Statistical analysis}

Student's t-tests were used to compare the descriptive statistics and parameters with a normal distribution. Pearson's chi-square tests were employed to compare the two groups based on qualitative variables. Statistical significance was defined at $\mathrm{p}<0.05$.

\section{RESULTS}

Of the 57 patients, 30 were treated with plate fixation and 27 with IMNs. The fracture was on the right side in 34 patients and the left side in 23 patients (Table I). According to Gustilo and Anderson classification, there were two type 1 open fractures $(3.5 \%)$ in the plate group and two type 1 open fractures (3.5\%) in the IMN group. ${ }^{[17]}$ The mean follow-up period was 25 months (range, $12-60$ months). A detailed analysis of the patients is presented in Table II.

The mean union time was $12.8 \pm 1.2$ weeks in the IMN group and $13.7 \pm 1.4$ weeks in the plate group. There was no statistically significant difference between the groups in terms of union time $(p=0.092)$. In the IMN group, union was achieved in all patients $(100 \%)$. For the plate group, union was achieved for all patients except one who developed a plate fracture in eighth postoperative month. This patient was evaluated as nonunion. An autograft from the iliac wing was conducted and osteosynthesis

TABLE I

Age and gender distribution in groups

\begin{tabular}{|c|c|c|c|c|c|c|c|c|}
\hline & \multicolumn{4}{|c|}{ Plate group } & \multicolumn{4}{|c|}{ Intramedullary nail group } \\
\hline & $\mathrm{n}$ & $\%$ & Mean & Range & $\mathrm{n}$ & $\%$ & Mean & Range \\
\hline Age (year) & & & 46.2 & $23-78$ & & & 31.3 & $18-67$ \\
\hline \multicolumn{9}{|l|}{ Gender } \\
\hline Male & 18 & 60 & & & 20 & 74.1 & & \\
\hline Female & 12 & 40 & & & 7 & 25.9 & & \\
\hline
\end{tabular}


TABLE II

Evaluation of parameters between groups

\begin{tabular}{|c|c|c|c|c|c|c|c|}
\hline & \multicolumn{3}{|c|}{ Plate group } & \multicolumn{4}{|c|}{ Intramedullary nail group } \\
\hline & $\mathrm{n}$ & $\%$ & Mean \pm SD & $\mathrm{n}$ & $\%$ & Mean $\pm S D$ & $p$ \\
\hline Time between injury and surgery (day) & & & $4.3 \pm 1.5$ & & & $4.4 \pm 1.9$ & $0.758 \dagger$ \\
\hline Operation time (minute) & & & $46.3 \pm 16.0$ & & & $30.5 \pm 6.0$ & $0.0001^{*} \dagger$ \\
\hline $\begin{array}{l}\text { AO/ASIF classification } \\
\text { a } \\
\text { b } \\
\text { c }\end{array}$ & $\begin{array}{c}22 \\
6 \\
2\end{array}$ & $\begin{array}{l}73.3 \\
20 \\
6.7\end{array}$ & & $\begin{array}{l}14 \\
11 \\
2\end{array}$ & $\begin{array}{c}51.9 \\
40.7 \\
7.4\end{array}$ & & $0.241 \ddagger$ \\
\hline Union time ( week) & & & $13.7 \pm 1.4$ & & & $12.8 \pm 1.2$ & $0.092 * \mathbb{\Upsilon}$ \\
\hline Pronation (degree) & & & $81.7 \pm 6.5$ & & & $80.7 \pm 8.3$ & $0.711 \dagger$ \\
\hline Supination (degree) & & & $81.7 \pm 5.9$ & & & $82.6 \pm 4.5$ & $0.596 \dagger$ \\
\hline Follow-up time (month) & & & $29.8 \pm 13.2$ & & & $21.6 \pm 7.6$ & $0.005^{\star} \mathbb{T}$ \\
\hline DASH score & & & $7.7 \pm 8.6$ & & & $7 \pm 4.5$ & $0.766 \dagger$ \\
\hline $\begin{array}{l}\text { Grace-Eversmann } \\
\text { Excellent } \\
\text { Good } \\
\text { Acceptable }\end{array}$ & $\begin{array}{c}24 \\
2 \\
4\end{array}$ & $\begin{array}{c}80 \\
6.7 \\
13.3\end{array}$ & & $\begin{array}{c}19 \\
7 \\
1\end{array}$ & $\begin{array}{c}70.4 \\
25.9 \\
3.7\end{array}$ & & $0.103 \ddagger$ \\
\hline Grip strength (kg) & & & $40.9 \pm 6.8$ & & & $41.4 \pm 7.8$ & 0.7659 \\
\hline
\end{tabular}

SD: Standard deviation; AO/ASIF: Association for Osteosynthesis/Association for the Study of Internal Fixation; $†$ Mann-Whitney $U$ test; $\ddagger$ Fisher-Freeman-Halton test; ๆ Student t-test; * $p<0.05$.

was performed with a longer plate; after 14 weeks, union was achieved. The mean operation time was significantly shorter in the IMN group (30 minutes) than in the plate group (46 minutes; $\mathrm{p}=0.0001$ ).

The mean DASH score was 7.0 \pm 4.5 in the IMN group and $7.7 \pm 8.6$ in the plate group. In addition, Grace-Eversmann evaluation produced the following classifications: 19 excellent (70.4\%), seven good $(25.9 \%)$, and one acceptable (3.7\%) for the IMN group, and 24 excellent $(80.0 \%)$, two good $(6.7 \%)$, and four acceptable (13.3\%) for the plate group. The difference between the groups in average DASH scores and Grace-Eversmann evaluation was not statistically significant $(\mathrm{p}>0.05)$.

The mean grip strength was $41.4 \pm 7.8 \mathrm{~kg}$ in the IMN group and $40.9 \pm 6.8 \mathrm{~kg}$ in the plate group. Mean supination was $82.6 \pm 4.5^{\circ}$ and pronation was $80.7 \pm 8.3^{\circ}$ in the IMN group, while mean supination and pronation were $81.7 \pm 5.9^{\circ}$ and $81.7 \pm 6.5^{\circ}$ in the plate group, respectively. There was no statistically significant difference between the groups in terms of grip strength, forearm pronation and supination ( $\mathrm{p}>0.05)$.

Complete elbow and wrist motion was achieved in all patients. In the plate group, one patient had pain and the implant was removed in the $24^{\text {th }}$ month, and no refracture occurred then. Superficial infection occurred in two patients in the plate group; both were treated with oral antibiotics and local wound care. Implants were not removed from any patient and no infection developed in the IMN group. No neurovascular damage and iatrogenic fracture occurred in either group.

\section{DISCUSSION}

To the best of our knowledge, no other research has compared plate and IMN osteosynthesis in isolated ulnar diaphyseal fractures in adults. In our study, the operation time was found to be higher for the plate group, while the union times and functional results were similar between groups. Ozkaya et al. ${ }^{[18]}$ treated 22 forearm fractures using plates and 20 fractures with closed reduction and locked IMNs; consequently, union was obtained in all patients, union was obtained at 10 weeks in the locked IMN group and at 14 weeks in the plate group; thus, union was achieved significantly earlier in the former. The two groups did not differ significantly with respect to functional results. In a study of Lee et al., ${ }^{[12]} 35$ forearm double fractures were treated with IMN and 32 forearm double fractures were treated with a plate, and above elbow casts were applied to the IMN group for six weeks. Consequently, union was achieved significantly earlier in the plate group (mean time, 10 weeks) than in the IMN group (mean time, 14 weeks). 
Union was obtained in all patients in the plate group and one nonunion occurred in the IMN group $(97 \%)$, while the functional outcomes did not significantly differ between the two groups. Köse et al. ${ }^{[19]}$ treated 42 forearm fractures using plates and 48 fractures with locked IMNs: mean operation time was 63.29 minutes (range, 40-100) in the plate group and 46.02 minutes (range, 17-85) in the IMN group, while the mean union time was 13.1 weeks (range, 10-20 weeks) and 10.8 weeks (range, 8-20 weeks), respectively. No statistically significant difference was determined in the Grace-Eversmann evaluation criteria, forearm supination, pronation degrees, and grip strength. In our study, union was achieved in all patients in the IMN group, and in 29 of the 30 patients in the plate group. The rates of union in our study were compatible with the literature and union times were similar between the groups. The operation time is shorter for IMNs because IMN is performed with mini incisions. However, the use of fluoroscopy is a disadvantage of IMNs. Surgeons who preferred to use plate in our clinic applied long arm splint for edema and pain control for two-three weeks while less pain and edema were seen after IMN since it was performed with mini incisions, and surgeons applying IMN began direct early active movement. The locked IMNs used in our study do not provide absolute stability like a plate; however, their relative stability allows for early movement, and this relative stability still meant that union was achieved in all patients. Complete elbow and wrist motion, similar degrees of forearm supination and pronation were achieved; as a result, differences in postoperative rehabilitation regimen did not affect outcomes. In our study, we achieved similar functional results between the groups and the results were compatible with the literature.

Plate osteosynthesis is widely used in adult forearm fractures and is the ideal treatment method. Since rotational stability cannot be obtained in forearm fractures treated with Kirschner-wire, Steinman pins and rush rods, the union rates are low; however, after locked IMNs were used in forearm fractures, higher union rates were obtained gradually. In a study of Saka et al., ${ }^{[13]}$ isolated ulnar fractures were treated with new generation locked IMNs, with mean union time of 13 weeks (range 10-14 weeks) and no patient having nonunion. ${ }^{[13]}$ Preoperative planning is important because if a thick nail is used, iatrogenic fracture may occur, while if a thin nail is used, instability may occur.

The retrospective design, difference in postoperative rehabilitation regimen, selection of surgical techniques based on the personal preference of the surgeon, and having different surgeons for each technique were the weaknesses of our study.

In conclusion, with similar union rates, functional results, and shorter operation times, locked IMNs are a suitable alternative to plate osteosynthesis in adult isolated ulnar diaphyseal fractures.

\section{Declaration of conflicting interests}

The authors declared no conflicts of interest with respect to the authorship and/or publication of this article.

\section{Funding}

The authors received no financial support for the research and/or authorship of this article.

\section{REFERENCES}

1. Rozental TD, Blazar PE. Fractures of the ulnar shaft: current treatment methods. Curr Opin Orthop 2005;16:240-4.

2. Atkin DM, Bohay DR, Slabaugh P, Smith BW. Treatment of ulnar shaft fractures: a prospective, randomized study. Orthopedics 1995;18:543-7.

3. Sauder DJ, Athwal GS. Management of isolated ulnar shaft fractures. Hand Clin 2007;23:179-84

4. Ekelund AL, Nilsson OS. Early mobilization of isolated ulnar-shaft fractures. Acta Orthop Scand 1989;60:261-2.

5. Mackay D, Wood L, Rangan A. The treatment of isolated ulnar fractures in adults: a systematic review. Injury 2000;31:565-70.

6. Atik OŞ, Odluyurt M, Özcan E, Savlık S. Ulna fracture and medial meniscal tear resulting from dog-related injuries. Eklem Hastalik Cerrahisi 2017;28:137-9.

7. Sarmiento A, Latta LL, Zych G, McKeever P, Zagorski JP. Isolated ulnar shaft fractures treated with functional braces. J Orthop Trauma 1998;12:420-3.

8. Ostermann PA, Ekkernkamp A, Henry SL, Muhr G. Bracing of stable shaft fractures of the ulna. J Orthop Trauma 1994;8:245-8.

9. Pearce PK, Handoll HH, Der T. Interventions for isolated diaphyseal fractures of the ulna in adults. Cochrane Database Syst Rev 2001;(2):CD000523.

10. Dodge HS, Cady GW. Treatment of fractures of the radius and ulna with compression plates. J Bone Joint Surg [Am] 1972;54:1167-76.

11. Chapman MW, Gordon JE, Zissimos AG. Compressionplate fixation of acute fractures of the diaphyses of the radius and ulna. J Bone Joint Surg Am 1989;71:159-69.

12. Lee SK, Kim KJ, Lee JW, Choy WS. Plate osteosynthesis versus intramedullary nailing for both forearm bones fractures. Eur J Orthop Surg Traumatol 2014;24:769-76.

13. Saka G, Sağlam N, Kurtulmuş T, Özer C, Uğurlar M, Akpinar $F$. Interlocking intramedullary ulna nails in isolated ulna diaphyseal fractures: a retrospective study. Acta Orthop Traumatol Turc 2013;47:236-43.

14. Duygun F, Aldemir C. Is locked compressive intramedullary nailing for adult humerus shaft fractures advantageous? Eklem Hastalik Cerrahisi 2017;28:80-6.

15. Grace TG, Eversmann WW Jr. Forearm fractures: treatment by rigid fixation with early motion. J Bone Joint Surg [Am] 1980;62:433-8. 
16. Hudak PL, Amadio PC, Bombardier C. Development of an upper extremity outcome measure: the DASH (disabilities of the arm, shoulder and hand) [corrected]. The Upper Extremity Collaborative Group (UECG) Am J Ind Med 1996;29:602-8.

17. Gustilo RB, Anderson JT. Prevention of infection in the treatment of one thousand and twenty-five open fractures of long bones: retrospective and prospective analyses. J Bone Joint Surg [Am] 1976;58:453-8.
18. Ozkaya U, Kiliç A, Ozdoğan U, Beng K, Kabukçuoğlu Y. Comparison between locked intramedullary nailing and plate osteosynthesis in the management of adult forearm fractures. Acta Orthop Traumatol Turc 2009;43:14-20.

19. Köse A, Aydın A, Ezirmik N, Yıldırım ÖS. A comparison of the treatment results of dpen reduction internal fixation and intramedullary nailing in adult forearm diaphyseal fractures. Ulus Travma Acil Cerrahi Derg 2017;23:235-44. 